\title{
PENGARUH KUALITAS PRODUK, HARGA DAN KUALITAS LAYANAN TERHADAP KEPUASANN PELANGGAN
}

\author{
(Studi kasus pada XL Center PT XL Axiata Tbk.) \\ Ahmad Maulana Irfanudin \\ Staf Pengajar Fakultas Ekonomi Universitas Pamulang \\ Email: irfand.azure@gmail.com
}

\begin{abstract}
ABSTRAK
Penelitian ini bertujuan "untuk menganalisis pengaruh kualitas produk, harga dan kualitas layanan secara simultan terhadap kepuasan pelanggan XL Center, untuk mengetahui pengaruh kualitas produk, harga dan kualitas layanan secara parsial terhadap kepuasan pelanggan XL Center, untuk mengetahui variabel mana yang paling mempengaruhi kepuasan pelanggan XL. Tengah. Dalam penelitian ini menggunakan variabel independen kualitas produk $\left(\mathrm{X}_{1}\right)$, harga $\left(\mathrm{X}_{2}\right)$ dan kualitas layanan $\left(\mathrm{X}_{3}\right)$. Metode analisis yang digunakan adalah analisis regresi linier berganda. Sampel yang digunakan dalam penelitian ini adalah 112 responden yang diambil secara acak dari pelanggan yang mengunjungi bintaro XL Center. Data yang diperoleh adalah data primer yang merupakan hasil jawaban responden terhadap kuesioner yang dibagikan. Hasil penelitian ini menunjukkan bahwa ada pengaruh simultan terhadap variabel kualitas produk, harga, dan kualitas layanan terhadap kepuasan pelanggan. Hasil penelitian ini juga menunjukkan bahwa variabel kualitas produk, harga dan kualitas layanan memiliki pengaruh signifikan secara parsial terhadap kepuasan pelanggan. Dalam uji determinasi terdapat pengaruh 54,5\% dari variabel independen (kualitas produk, harga, dan kualitas layanan) terhadap variabel dependen (kepuasan pelanggan). 45,5\% sisanya dijelaskan oleh variabel lain dan tidak termasuk dalam analisis regresi ini”.
\end{abstract}

Kata kunci: kualitas produk, harga, kualitas layanan, kepuasan pelanggan

\begin{abstract}
This research has purpose to "analyze the influence of product quality, price and service quality simultaneously to XL Center customer satisfaction, to know the effect of product quality, price and service quality partially to XL Center customer satisfaction, to know which variable most influence on XL Center customer satisfaction. This research use independent variable of product quality $\left(X_{1}\right)$, price $\left(X_{2}\right)$ and service quality $\left(X_{3}\right)$. The analytical method used multiple linear regression analysis. The sample used in this study were 112 respondents taken randomly from customers who visited XL Center bintaro. The data obtained is the primary data which is the result of the respondent's answer to the distributed questionnaire. The results of this study indicate that there is simultaneous influence on variable quality of product, price, and quality of service to XL Center customer satisfaction. The results of this study also showed that product quality, price and service quality variables significantly influence partially on customer satisfaction. In the determination test there is an effect of $54.5 \%$ of the independent variables (product quality, price and service quality) to the dependent variable (customer satisfaction). The remaining $45.5 \%$ is explained by other variables not included in this regression analysis".
\end{abstract}

Keywords: product quality, price, service quality, customer satisfaction 


\section{PENNDAHULUAN}

\section{A. Latar Belakaang}

Yang dimaksud dengan koomunikasi adalah "suatu prroses ataau keggiatan peenyampaian pesan dari sesseorang kepada orang laiin untuk mencapaai suatu tujuann". "Komunikasi merupakan "prassyarat kehidupan seorang manusia". "Kehidupan manusia akan terasa hampa jika tanpa adanya komunikasi. Globalisasi membawa dampak yang sangat besar bagi pertumbuhan pada bisnis jasa telekomunikasi yang di Indonesia, sehingga menciptakan pasar yang terbuka luas dan peluang menjadi semakin lebar dan kuat, hal ini diikuti berkembangnya berbagai macam jenis perusahaan jaringan telekomunikasi selular di Indonesia, salah satunya adalah PT. XL Axiata Tbk. Melalui kepuasan pelanggan, diharapkan tercipta kesetiaan pelanggan dimana pelanggan akan melakukan suatu pembelian atau penggunaan jasa secara berkala, pelanggan sulit terpengaruhi oleh perusahaan provider lain yang sejenis dan juga akan membentuk suatu promosi gratis perusahaan yaitu dengan memberikan beberapa saran yang positif dari mulut ke mulut yang baik kepada para pelanggan. Dalam meningkatkan kepuasan dari para pelanggan, strategi yang paling cepat untuk target peningkatan laba yang tetap merupakan konsumen yang selalu setia. Oleh karenanya, perusahaan harus mampu mengidentifikasikan, mempertahan-kan dan memperkuat kepuasan pelanggan. Kepuasan pelanggan akan menjadi kunci bagi perusahaan-perusahaan yang ingin memenangkan persaingan di era globalisasi ini”.
"Menyadari kenyataan akan adanya pesaing yang semakin ketat dan sehat antar sesama penyedia layanan jasa telekomunikasi selular dan lainnya maka perusahaan yang bergerak di bisnis telekomunikasi ini dituntut untuk senantiasa mempertahankan serta dapat meningkatkan kualitas layanan, memperluas teknologi dan kualitas produk serta penetapan harga yang sesuai dengan keadaan pasar. Kuualitas pellayanan merrupakan "satu bentuk penilaian pengguna terhadap tahap perkhidmatan yang dirasakan (perceived service) dengan tahap perkhidmatan yang diharapkan (expected service)". Agar kuaalitas playanan yang prima kepada konsumen, manajemen perusahaan perlu mengidentifikasi kesenjangan yang mungkin terjadi dan pengaruhnya terhadap kepuasan pelanggan". Melalui pemahamaan mengenai kualitas pelayanan yang dapat mempengaruhi volume penjualan yang optimal".

"Seiring dengan moto terbarunya", "Sekarang Bisa!", "PT XL Axiata, tbk (XL) terus berupaya menjadi yang terdepan dalam kenyamanan bagi pelanggannya dengan menghadirkan jaringan terbaik dan kantor pelayanan yang mudah dikunjungi". 'Hal ini dibuktikan oleh semakin meningkatnya pelayanan pelanggan lewat XL Center, sebagai wadah usaha yang lebih memfokuskan pellayanan, serta memahami segala kebutuhan pelanggan. XL Center berkomitmen dengan Service Level Agreement (SLA), dan kualitas pelayanan yang tetap terjaga'. "XL Center memberikan pelayanan paripurna baik pelayanan sebelum penjualan (before sales) yang meliputi informasi produk dan layanan, hingga ke pelayanan after 
sales seperti penggantian kartu (card replacement) rusak atau hilang, pelayanan gadget untuk smartphone, pembayaran tagihan XL pasca-bayar, penjualan pulsa dan kartu perdana, pelayanan XL Tunai, serta pelayanan-pelayanan lainnya. Berikut ini merupakan data penjualan produk XL di XL Center Bintaro selama 6 bulan terakhir" (Januari s.d. Juni 2017):

\section{Gambar 1}

Grafik Summary MSR (Monthly Sales Report) XL Center Januari -

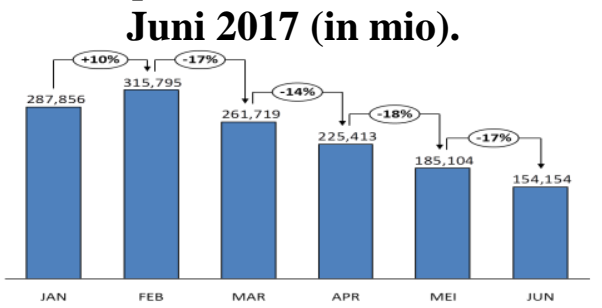

Dilihat dari grafik tersebut terjadi kenaikan penjualan dari bulan Januari ke Februari 2017, lalu mulai mengalami penurunan di bulan maret dan seterusnya hingga Juni 2017.

Dalam pelaksanaannya, masih terdapat keluhan yang disampaikan oleh pelanggan terkait dengan kualitas pelayanan yang diberikan XL Center. Hal ini dilihat dari banyaknya complaint yang disampaikan melalui call center

Gambar 2

Diagram Komplain Pelanggan

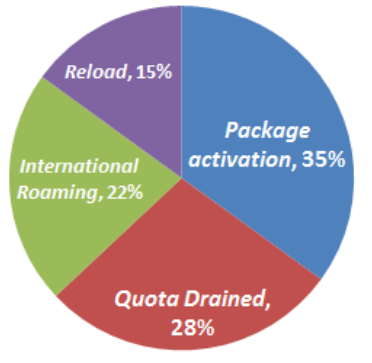

"Untuk melihat peluang dan tantangan yang dihadapi perusahaan dalam menghadapi persaingan dunia bisnis khususnya dalam pelayanan jasa telekomunikasi selular, maka dilakukan penelitian pada perusahaan PT XL Axiata Tbk dengan judul penelitian": "Pengaruh Kualitas Produk, Harga, dan Kualitas Layanan terhadap Kepuasan Pelanggan (Studi kasus pada XL Center PT XL Axiata Tbk.)".

\section{B. Perumussan Massalah}

Setelah dilakukan penjabaran dalam analisis, dapat dibuat suatu peruumusan massalah adalah:

1. Apakaah kualiitas prooduk secara satu persatu mempunyai pengaruh terhadap variabel kepuasan pelanggan ?

2. Apakah harga secara satu persatu mampu mempunyai pengaruh terhaadap varriabel kepuasan pelanggan?

3. Apakah kuaalitas pellayanan secara satu persatu memiliki pengaruh terhadap variabel kepuaasan peelanggan?

4. Apakah kuualitas prooduk, harrga dan kuaalitas pealayanan secara bersamaan memiliki pengaruh secara bersamaan terhadap kepuasan pelanggan ?

\section{Tujuuan Peenelitian}

Setelah dibuat perumusan masalah dan analisa yang dijabarkan pada latar belakang di atas. Adapun tujuan penelitian adalah:

1. Untuk mengethui pengaruh variable kuualitas prooduk secara satu persatu terhadap keppuasan pelanggaan.

2. Untuk mengetahui pengaruh variablle harrga secara satu persatu terhadap variiabel kepasan pellanggan. 
3. Untuk mengetahui pengaruh vaariable kualitaas pellayanan secara satu persatu terhadap kepuasn pelannggan.

4. Untuk meengetahui pengaruh variable kualitas produk, harga, dan kualitas pelayanan secara bersamaan terhadap kepuasan pelanggan.

\section{TINJAUAN PUSTAKA}

\section{A. Pengertian Maanajemen}

"Ricky W. Griffin (2002) berkata, Manajemen adalah proses perencanaan, pengorganisasian, pengoordinasian dan pengendalian atau kontrol sumber daya dalam mencapai sasaran dengan efisien dan efektif". "Sedangkan manajemen menurut Kottler dan Keller (2006:6) adalah "Penganalisaan, perencanaan, pelaksanaan program-progam yang ditujukan untuk mengadakan pertukaran dengan pasar yang dituju untuk mencapai tujuan organisasi”.

"Dari beberapa pendapat tersebut di atas penulis menarik kesimpulan bahwa manajemen adalah proses perencanaan, pengorganisasian, peaksanaan dan pengawasan kegiatan-kegiatan dalam suatu organisasi yang sudah direncanakan dengan efisien untuk mencapai tujuan yang telah ditetapkan oleh organisasi tersebut".

\section{B. Penggertian Manjemen Pmasaran}

"Kotler (2000:9) berkata yang dimaksud dengan manajemen pemasaran merupakan proses perencanaan dan pelaksanaan dari perwujudan, pemberian harga, promosi, dan distribusi dari barangbarang, jasa dan gagasan untuk menciptakan pertukaran dengan kelompok sasaran yang memenuhi tujuan pelanggan dan organisasi”.
Unsur-unsur utama dapat diklarifikasikan sebagai berikut ini:
a. Unsure Strateegi Peersaingan
b. Unsuur Takktik Pemmasaran
c. Unnsur Niilai Pemassaran marketig

\section{Bauran Pemasaran}

"Bercakap mengenai pemasaran tidak dapat dipisahkan dari campuran pemasaran, yang merupakan salah satu konsep utama dalam teori pemasaran atau teras kegiatan pemasaran sendiri.", seperti dijelaskan oleh Kotler (2006:92), "marketing mix is the set of marketing tools that the firm to uses to pursue its marketing objectives in the target market". Pendapat itu memberikan penjelasan mengenai "bauran pemasaran adalah sejumlah alat pemasaran yang digunakan oleh perusahaan untuk meyakinkan objek pemasaran atau pasar yang ditargetkan".

"Ketika membahas strategi untuk memasarkan barang, pemasar biasanya memperhatikan empat elemen strategi dasar, yaitu: produk, harga, tempat (atau distribusi) dan promosi (komunikasi). Tetapi sifat layanan, yang melibatkan berbagai aspek keterlibatan pelanggan dalam produksi dan pentingnya faktor waktu, memerlukan elemen strategis lainnya".

\section{Gammbar 3 \\ 4P dalaam Baauran Peemasaran}

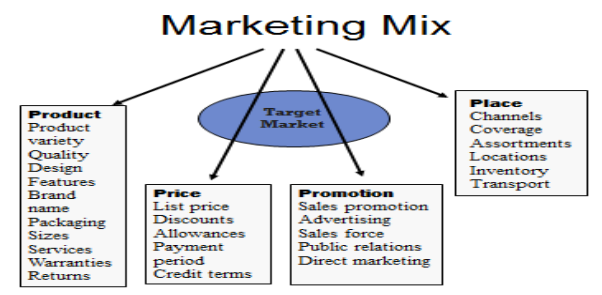

Loveelock dan Wriight (2002:13-5) berkata bahwa yang dimaksud dengan "bauuran pemmasaran 
menjadi layanan terintegrasi dari suatu manajemen menggunakan pendekatan 8P terintegrasi", yaitu "product elements, place, cyberspace, and time promotion and education, price and other user outlays, process, productivity and quality, people and physical evidence".

Gammbar 4

Markeeting Miix

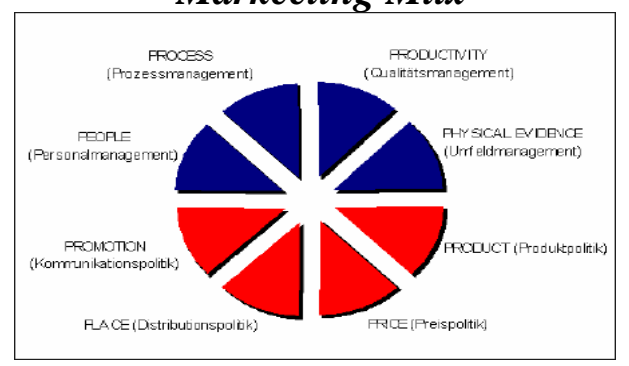

Pengurusan atas perkhidmatan bersepadu adalah perancangan dan pelaksanaan terkoordinasi kegiatankegiatan pemasaran, operasi dan sumber daya manusia yang penting untuk keberhasilan perusahaan jasa.

\section{Elemeen Harga (Priice)}

Kotler dan Amstrong (2008:519) dalam bukunya berkata "Harga merupakan satu-satunya elemen dari bauran pemasaran yang menghasilkan pendapatan, elemenelemen lainnya menimbulkan biaya."

Greggorius (2002:152) dalam bukunya mengemukakan bahwa "Harga merupakan aspek yang tampak jelas (visible) bagi para pembeli. Bagi konsumen yang tidak terlalu paham hal-hal teknis pada pembelian produk otomotif dan elektronik, kerapkali harga menjadi satu-satunya faktor yang dapat mereka mengerti. Tidak jarang pula harga di jadikan semacam indikator kualitas".
1. Faktor Yang mampu/dapat Mempengaruhi Harga

Diantara faktor-faktor yang dapat mempengaruhi harga adalah:

a. "Keadaan ekonomi sangat mempengaruhi tahap harga semasa. Dalam tempoh kemelesetan ialah tempoh dimana harga pada tahap murah".

b. Bekalan dnan Permiintaan. "Permintaan adalah beberapa barang yang dibeli oleh pembeli pada tahap harga tertentu, secara amnya paras harga yang lebih rendah akan menghasilkan lebih banyak item yang diminta. Penawaran adalah beberapa produk yang ditawarkan oleh penjual pada tahap harga tertentu. Secara umum, harga yang lebih tinggi memacu jumlah yang ditawarkan lebih tinggi".

c. "Keanjalan Permintaan Barang. Sebenarnya sifat permintaan untuk pasaran tidak hanya mempengaruhi penentuan harganya tetapi juga mempengaruhi volume yang dapat dijual. Bagi sesetengah jenis barangan, harga dan jumlah jualan adalah berkadar songsang, bermakna bahawa jika terdapat kenaikan harga, jualan akan berkurangan dan sebaliknya".

d. "Persaiingan, harga jualan beberapa jenis barang sering dipengaruhi oleh keadaan persaingan. terdapat beberapa keadaan persaingan, iaitu: persaingan tulen, persaingan tidak sempurna, oligopoli dan monopoli".

e. "Biayya, adalah asas untuk harga, kerana harga yang tidak dapat menampung kos pengeluaran akan berakibat pada kerugian". 
f. Tujuan perusahaan, harga barang sering dikaitkan dengan objektif syarikat. Objektif yang akan dicapai termasuk: keuntungan maksimum, jumlah jualan tertentu, bahagian pasaran, dan pulangan atas modal tertanam dalam tempoh tertentu.

g. Pengawasan kerajaan dapat direalisasikan dalam bentuk harga maksimum dan harga minimum, diskriminasi harga, dan amalan lain yang mendorong atau mencegah upaya menuju monopoli.

"Harga boleh menunjukkan kualiti jenama produk, di mana pengguna menganggap bahawa harga mahal biasanya mempunyai kualiti yang baik. Secara umum, harga mempunyai pengaruh positif terhadap kualiti, semakin tinggi harga semakin tinggi kualiti”.

"Pelanggan menganggap bahawa terdapat hubungan positif antara harga dan kualiti produk, Jika produk memerlukan pengguna untuk membelanjakan lebih daripada manfaat yang diterima, maka apa yang terjadi ialah produk mempunyai nilai negatif sehingga tahap kepuasan pelanggan akan berkurang, dan sebaliknya".

"Oleh itu, harga yang betul dan berpatutan ditentukan oleh XL akan dapat memberikan kepuasan yang berlebihan kepada pengguna kerana ia seimbang dengan perkhidmatan yang sangat baik. Ini akan meningkatkan bahagian pasaran dan akan mempunyai pengaruh ke atas tahap pendapatan”.
Stanton dalam buku Rosvita (2010:24) berpendapat bahawa penunjuk harga, iaitu:
a. Modal yang terjangkau terjangkau
b. modal dan kualitas produk yang sesuai.
c. Persaingan dari harga barang, dan
d. Modal dan manfaat yang sesuai.

\section{E. Elemen Produk}

\section{Pengertian Produk}

Kotler dan Armstrong (2006:274) dalam bukunya menyatakan bahwa prodduk merupakan: "Segala sesuatu yang ditawarkan ke pasar untuk mendapatkan perhatian, dibeli, dipergunakan dan yang dapat memuaskan keinginan atau kebutuhan konsumen". Tjiptono (2009) berpendapat bahawa secara konseptual produk itu disebut sebagai "pemahaman subjektif pengeluar" sesuatu "yang boleh ditawarkan sebagai usaha untuk mencapai matlamat organisasi melalui memenuhi keperluan dan keinginan pengguna, sesuai dengan kompetensi dan kemampuan organisasi dan daya beli".

\section{Pengertian Kualitas Produk}

Kottler dan Armmstrong (2012:283) menyatakan "kualitas prroduk adalah kemmampuan suatu produk untuk melaksanakan fungsinya, meliputi daya tahan, keandalan, ketepatan, kemudahan operasi dan perbaikan, serta atribut bernilai lainnya".

Tjiptono (2009), di dalam bukunya mengatakan bahwa 
kualitas produk memiliki dimensi - dimensi yang meliputi:

a. Kiinerja (performance)

"Kinerja (performance) adalah karakteristik opeerasi pokok dari prodduk inti (core product) yang dibeli, misalnya Kualitas jaringan telepon yang jernih, kecepatan akses data (internet), keemudahan dan memberi kenyamaanan dari aktivitas selular dan lainnya".

b. Keisitimewaan Tammbahan dari suatu Produk (Features)

"Features adalah suatu karakteristik sekunder atau pelengkap, misalnya layanan prioritas dari pelanggan dari pascabayar".

c. Keandalann (Reliiability)

"Keandalan adalah suatu kemungkinan kecil yang akan mengalami kegagalan fungsional, misalnya akses jaringan atau internet yang terbatas di daerah terpencil".

d. Kesesuuaian produk dengan spesifiikasi (conformance to product specifications)

"Sejauh mana suatu produk dalam karakteristik desain dan operasi dalam memenuhi standar - standar yang telah ditetapkan sebelumnya. Yaitu dengan penentuan jumlah kuota data internet atau kesesuaian tarif dan jaringan telepon".

e. Daaya tahhan (Durrability)

"Daya tahan sangat berkaitan dengan berapa lama produk tersebut dapat terus dipakai". f. Estetikka (Astheethic)

"Estetika aadalah daya tarik dari suatu produk yang berdasarkan panca indra. Misalnya dengan bentuk pengemasan produk yang menarik, model dan desain yang artistic"

g. Kesan Kualitas (Perceived quality)

"Pandangan atau suatu pendapat pelanggan terhadap kualitas produk".

Dalam penelitian ini diambil aspek-aspek dimensi Produk sebagai tolak ukur pembeda antara produk XL dengan produk kompetitor.

\section{F. Kepuasan Pelanggan}

\section{Pengertian Dari Kepuassan} Pelanggan

Definisi dari kepuasan pelanggan menurut Kotler dalam bukunya dengan judul marketing of management (2003:264) "Satisfaction is a person feelings of peasure or disspointment resulting from comparing a product's perceived performance (or outcome) in telation to his or her expectation". Iaitu, kepuasan terhadap pelanggan adalah tahap perasaan seseorang selepas membandingkan prestasi yang dia rasa dibandingkan dengan harapannya. Ia semakin diakui bahawa kepuasan adalah satu aspek yang penting untuk dapat ditahan dalam perniagaan dan memenangi pertandingan.

\section{Fakktor - Fakttor Keppuasan} Pelanggan

Menurut Javan Chia-Jung Hsu dan Chao Min Hsu, Kun 
Shan (2008) dalam pelanggan terdapat

"kepuasan faktor yang mesti dipenuhi, termasuk":

a. Repeeat purcchase yaitu "pelanggan mengulangi pembelian atau menambahkan membeli produk baru;

b. Referrals yaitu kesediaan customer untuk memberikan referensi kepada orang lain;

c. Perceived value yaitu pendapat pelanggan terhadap nilai dari bentuk produk yang membeli;

d. Customer expectations meliputi produk yang dibeli memenuhi semua pengharapan dari customer;

e. Customer complaints, vendor penyedia jasa / produk mengakomodir keluhankeluhan dari customer.

Tidak mengherankan bahwa perusahaan telah menjadi terobsesi dengan kepuasan pelanggan, mengingat hubungannya yang langsung dengan kesetiaan pelanggan, pangsa pasar dan keuntungan.

Pada penelitian ini, untuk mengukur kepuasan pelanggan XL Center menggunakan elemen Expectation (kesesuaian) yakni perbandingan yang dilakukan oleh pelanggan yang membandingkan antara tingkatan dari faedah yang dijangkakan manfaat yang diharapkan oleh pelanggan, dan After service yakni kepuasan pelanggan terhadap produk yang dibeli dan Kepuasan terhadap pelayanan yang diberikan.

\section{G. Kualitas Layanan}

1. Pengertian Kualitas Layanan

"Pelanggan biasanya dapat mengharapkan produk dalam bentuk barang/perkhidmatan yang mereka gunakan untuk diterima atau dinikmati oleh perkhidmatan yang baik atau memuaskan. Dengan kata lain, pelanggan mahukan kualiti perkhidmatan yang disediakan adalah baik dan membuatnya berpuas hati. Syarikat perlu memberi perhatian kepada kualiti perkhidmatan (kualiti dari perkhidmatan) dan perkhidmatan yang disediakan oleh syarikat mereka. Dalam kes ini, syarikat itu sememangnya bertujuan menyediakan perkhidmatan atau perkhidmatan yang baik kepada para pelanggannya. Ini adalah usaha syarikat untuk kelihatan berbeza daripada pesaingnya".

Menurut Tjiptono (2009): "Kualitas jasa atau kualitas pelayanan yang mendefinisikan sebagai kondisi dinamis yang berhubungan dengan produk, jasa, sumber daya manusia, proses dan lingkungan yang memenuhi atau melebihi harapan."

\section{Pengukuran Kualitas Layanan}

Mengenai pengukuran

kualitas, Tjiptono (2009) telah membangunkan mengenai kualiti perkhidmatan yang dipanggil SERVQUAL (Service Quality). SERVQUAL ini adalah skala pelbagai item yang terdiri daripada soalan yang boleh digunakan untuk mengukur persepsi pelanggan terhadap 
kualiti perkhidmatan yang meliputi 5 dimensi, iaitu:

a) Realibility, yaitu "keupayaan untuk menyediakan suatu perkhidmatan yang sesuai dijanjikan dengan tepat dan memuaskan".

b) Responsiveness, yaitu "tindak balas atau kewaspadaan pekerja dalam membantu pelanggan dan menyediakan perkhidmatan yang cepat dan responsif".

c) Assurance, "yang termasuk keupayaan pekerja untuk: pengetahuan tentang produk dengan sewajarnya, kualiti hospitaliti, perhatian dan kesopanan dalam upaya menyediakan perkhidmatan, kemahiran dalam upaya menyediakan maklumat, keupayaan untuk dapat menyediakan keselamatan untuk barangan atau perkhidmatan yang dapat diharapkan, dan keupayaan untuk memupuk kepercayaan pelanggan di syarikat, bebas daripada bahaya, risiko dan keraguan".

d) Emphaty, yaitu "perhatian secara individual yang diberikan perusahaan kepada pelanggan, seperti memberi kemudahan untuk dapat menghubungi perusahaan, memberikan kemampuan karyawan untuk dapat berkomunikasi dengan pelanggan, dan usaha perusahaan untuk memenuhi keinginan dan harapan pelanggannya". e) Tangibles, "yang termasuk penampilan fizikal seperti bangunan untuk syarikat, ketersediaan pejabat depan, ketersediaan tempat letak kereta, keselesaan dan kemahiran dalam penampilan pekerja".

Dari penjelasan di atas dapat dipahami bahwa kualitas layanan tidak hanya ditentukan oleh satu faktor seperti kemampuan karyawan ketika menghadapi pelanggan, akan tetapi lebih penting lagi bagaimana perusahaan dengan segala sumber daya yang dimilikinya dapat memberikan kepuasan kepada pelanggan.

Selanjutnya kepuasan pelanggan akan muncul apabila sesuatu yang mereka harapkan dari layanan jasa tertentu terpenuhi. Dengan kata lain, antara harapan dengan layanan yang mereka rasakan tidak berbeda sama sekali.

\section{H. Hipotesis Penelitian}

"Berdasarkan penjelasan dari kerangka pemikiran di atas sesuai dengan tujuan penelitian untuk menjawab pertayaan penelitian, maka hipotesis yang diuji adalah sebagai berikut":

1. $\mathrm{H}_{\mathrm{a}}$ : Secara bersamaan tidak memiiki pengaruuh antaara kualitaas produkk, harga, dan kuaalitas layyanan terhadap Kpuasan Pelaanggan

$\mathrm{H}_{\mathrm{o}}$ : secara bersamaan tidak memiliki pengaruh antara Kuaalitas Produk, Harga, dan Kulitas Layanaan terhadap Kepuasan Pelanggan 
2. $\mathrm{H}_{\mathrm{a}}$ : secara satu persatu tidak memiliki pengaruh antara kualitas produuk terhadap kepuasan pelanggan.

$\mathrm{H}_{\mathrm{o}}$ : secara satu persatu tidak memiliki pengaruh antara kualitas produk terhadap kepuasan pelanggan.

3. $\mathrm{H}_{\mathrm{a}}$ : secara satu persatu tidak memiliki pengaruh antara harga terhadap kepuasan pelanggan.

$\mathrm{H}_{\mathrm{o}}$ : secara satu persatu tidak memiliki pengaruh antara harga terhadap kepuasan pelanggan.

4. $\mathrm{H}_{\mathrm{a}}$ : secara satu persatu tidak memiliki pengaruh antara Kualitas layanan terhadap kepuasan pelanggan.

$\mathrm{H}_{\mathrm{o}}$ : secara satu persatu tidak memiliki pengaruh antara kualitas layanan terhadap kepuasan pelanggan.

\section{METODLOGI PENLITIAN}

Lokasi dalam penelitian ini adalah XL Center Bintaro, JL.M.H Thamrin, Bintaro Jaya Sektor 7, Tangerang Selatan. Metode yang digunakan untuk penelitian ini adalah "metode kuantitatif". Metode kuantitatif digunakan "untuk meneliti pada populasi atau sampel tertentu, teknik pengambilan sampel pada umumnya dilakukan secara random, pengumpulan data menggunakan instrumen penelitian, analisis data bersifat kuantitatif / statistik dengan tujuan untuk menguji hipotesis yang telah ditetapkan" (Sugiyono, 2009: 13).

Bila dilihat dari tujuan penelitiannya, yang digunakan dalam penelitian ini adalah "gabungan tipe causal dan deskriptif". Riset dekriptif digunakan untuk memberikan gambaran terhadap karakteristik pasar, dalam hal ini responden, sedangkan tipe kausal yaitu penelitian yang mengukur kekuatan hubungan dua variabel atau lebih, juga untuk menunjukkan arah hubungan antara variabel bebas dengan variabel terikat (Kuncoro, 2009:72), berguna untuk menganalisis hubungan-hubungan yang saling mempengaruhi sehingga dalam penelitian ini akan meneliti pengaruh variabel $\mathrm{X}_{1}, \mathrm{X}_{2}$ dan $\mathrm{X}_{3}$ terhadap variabel $\mathrm{Y}$.

Populasi dalam penelitian ini adalah pelanggan jasa provider XL yang mengunjungi XL Center.

Sampel adalah "bagian dari jumlah dan karateristik yang dimiliki oleh populasi tersebut. Bila populasi besar, dan penelitian tidak mungkin mempelajari semua yang ada pada populasi, misalnya keterbatasan dana, tenaga dan waktu maka penelitian dapat menggunakan sampel yang diambil dari populasi itu" (Sugiyono, 2008). Populasi dalam penelitian ini merupakan "populasi tidak terbatas". Menurut Wibisono dalam Riduwan dan Akdon (2013), "rumus dalam menghitung sampel pada populasi yang tidak diketahui adalah sebagai berikut":

$$
n=\left(\frac{Z_{\alpha / 2} \sigma}{e}\right)^{2}=\left(\frac{(1,96) \cdot(0,25)}{0,05}\right)^{2}=96,04
$$

Dengan tingkat kepercayaan 95\% didapat ukuran sampel minimal sebesar 96,04 $\approx 97$ akan 
memberikan selisih estimasi $\bar{x}$ dengan $\mu$ kurang dari 0,05 .

Dalam penelitian ini, peneliti menyebarkan kuisioner sebanyak 120 lembar dan data yang kembali kepada peneliti sebanyak 112 jawaban responden, karena sampel sudah memenuhi ukuran sampel minimal, data ini kemudian menjadi data penelitian.

Metode pengambilan sampel dari penelitian ini adalah "non probability sampling”. Non probability samping adalah "teknik pengambilan sampel yang tidak memberi peluang atau kesempatan sama bagi setiap anggota populasi untuk dipilih menjadi sampel" (Sugiyono, 2009).

Metode yang digunakan dalam pengumpulan data ini adalah "metode survey", sedangkan pengumpulan data dalam penelitian ini adalah "dengan menggunakan kuesioner". Untuk data sekunder, pengumupulan data dilakukan dengan studi literatur dan pencarian data di jurnal-jurnal yang meneliti topik sejenis.

Bentuk pertanyaan digunakan dalam kuesioner adalah "Structure Non Disguised yaitu bentuk pertanyaan yang merupakan kombinasi pilihan ganda yang berpedoman kepada skala likert yang digunakan untuk mengukur sikap, pendapat, dan persepsi bagi seorang responden". Bentuk penilaian jawaban kuesioner menggunakan pembobotan 5 buah skala (Sugiyono, 2009).
IV. HASIL DAN PEMBAHASAN

A. Gambaran Umum Perusahaan

1. Sejarah XL Center

XL Center sebagai salah satu unit XL yang memberikan pelayanan paripurna baik pelayanan sebelum penjualan (before sales) yang meliputi informasi produk dan layanan, hingga ke pelayanan after sales seperti penggantian kartu (card replacement) rusak atau hilang, pelayanan gadget untuk smartphone, pembayaran tagihan XL pascabayar, penjualan pulsa dan kartu perdana, pelayanan XL Tunai, serta pelayanan-pelayanan lainnya.

2. Visi Dan Misi XL Center - PT XL Axiata Tbk.

a. Visi:

Visi XL Center sebagai salah satu bagian dari PT XL Axiata adalah menjadi pusat informasi dan pelayanan bagi pelanggan XL, XL Memiliki visi menjadi penyedia teknologi informasi dan komunikasi terbaik di Indonesia.

b. Misi:

Dalam usaha memberikan pelayanan yang unggul, unit XL Center memiliki misi mencerminkan perilaku inti yaitu Fokus pada pelanggan, Berorientasi pada solusi terbaik, Efektif dan Efisien dalam menghasilkan solusi, "Secara sepenuh hati dalam menjalankan tugas-tugas, Berorientasikan kepada kualiti produk dan perkhidmatan yang disediakan, Proaktif dalam bertindak dan Inovatif dan Kreatif dalam menyediakan penyelesaian (Service Excellent, XL Center)". 


\section{Struktuur Orrganisasi}

Berikut adalah gambar struktur organisasi dari perusahaan:

Gambar 5

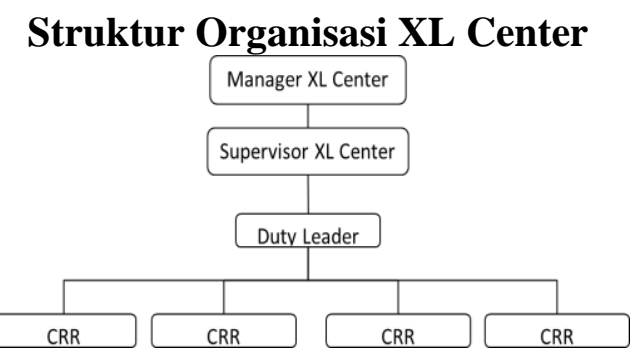

Sumber: Service Excellent, XL Center-PT XL Axiata

\section{B. Hassil dan Peembahasan}

\section{Hassil Ujji Valiiditas dann Reabilitas}

"Kuesioner dibagi dalam empat faktor utama, yaitu Kualitas Produk $\left(\mathrm{X}_{1}\right)$ dengan 10 butir pernyataan, Harga $\left(\mathrm{X}_{2}\right)$ dengan 10 butir pernyataan, Kualitas Pelayanan $\left(\mathrm{X}_{3}\right)$ dengan 12 butir pernyataan dan Kepuasan Pelanggan (Y) dengan 11 butir pernyataan, jumlah pernyataan dalam kuesioner sebanyak 43 butir pernyataan dengan jumlah responden sebanyak 112".

"Hasil pada penelitian menunjukkan bahwa dari pengujian validitas seluruh butir pernyataan yang mempunyai nilai $r$ hitung $\quad \mathrm{df}=\mathrm{n}-2=110$ yaitu 0.186. semua butir pernyataan > 0.186 Sehingga butir-butir pertanyaan dalam kuesioner tersebut dapat dikatakan valid dan dapat dijadikan acuan untuk penelitian selanjutnya".
Ukuran validitas tiap butirbutir pernyataan dapat dilihat dalam tabel di bawah ini:

Table 1

Ujii Valiiditas Kualitaas Prooduk $\left(\mathrm{X}_{1}\right)$

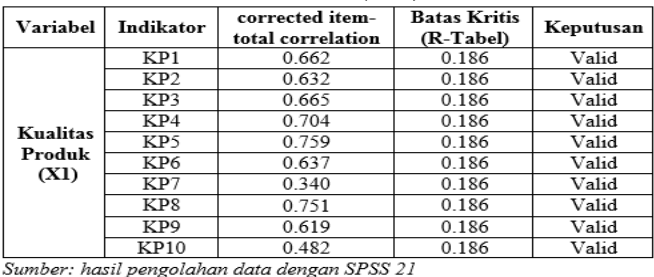

Table 2

Uj.ji Vaaliditas Harrga $\left(\mathbf{X}_{2}\right)$

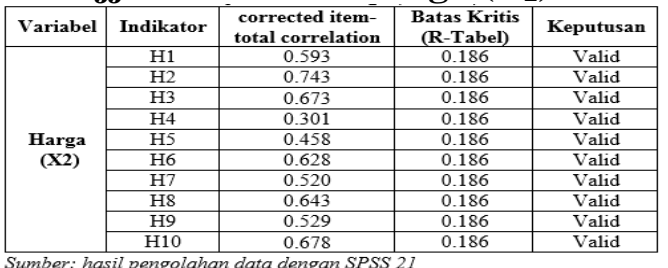

Tabel 3

Uji Valliditas Kuaalitas Laayanan $\left(\mathbf{X}_{3}\right)$

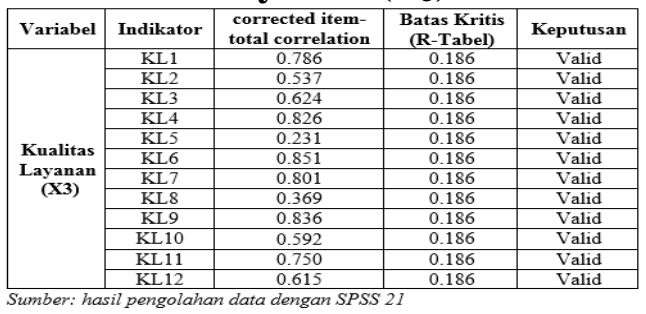

Tabel 4

Uji Valiiditas Keepuasan Pelanggaan (Y)

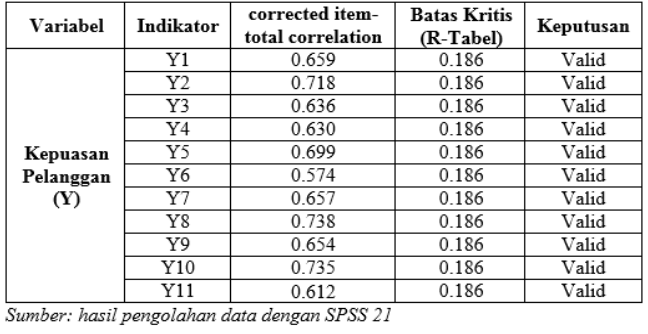

"Berdasarkan keterangan tabel diatas menunjukkan setiap butir pernyataan dari setiap variabel dalam penelitian ini mempunyai nilai corrected item- 
total correlation lebih besar dari 0,186. Bahwa butir-butir pertanyaan yang digunakan untuk mengukur tiap-tiap variabel valid dan dapat dilanjutkan dalam pengujian selanjutnya".

"Dengan kata lain, indikator yang valid atau sah menjadi salah satu ukuran atas kemampuan penjelasan terhadap variabel yang sedang diteliti sesuai dengan teori dan empiris".

\section{Hassil Ujji Asuumsi Kllasik}

\section{a. Haasil Ujji Noormalitas Daata}

"Uji normalitas digunakan untuk melihat apakah nilai residual terdistribusi normal atau tidak. Untuk mendeteksi apakah residual berdistribusi normal atau tidak yaitu dengan melihat normal probability plot yang membandingkan distribusi kumulatif dari distribusi normal. Normalitas dapat dideteksi dengan melihat penyebaran dan (titik) pada sumbu diagonal dari grafik". Berikut hasil gambar normalitas:

\section{Gambar 6}

\section{Grafikk Norrmal P-Plot}

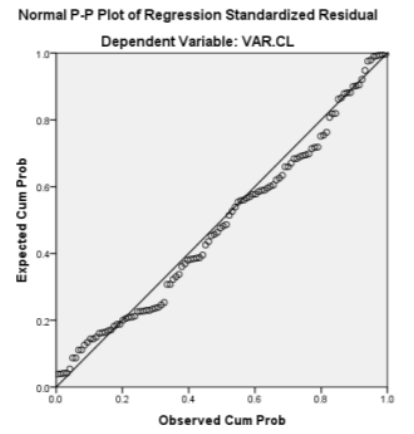

Melihat tampilan grafik normal probability plot di atas, dapat disimpulkan bahwa "pada grafik normal probability plot terlihat titiktitik menyebar di sekitar garis diagonal dan penyebarannya mengikuti arah garis diagonal, sehingga dapat disimpulkan bahwa data yang diuji berdistribusi normal".

\section{b. Hasiil Uji Multikoolnearitas}

"Untuk mengetahui besar atau tidaknya pengaruh variabel independen atau bebas, metode yang digunakan adalah metode VIF (Variance Inflation Factor). Bila menggunakan metode VIF, jika terdapat varian dibawah 10, maka tidak terdapat masalah multikolinieritas. Berikut hasil uji multikolinieritas":

Tabel 5

\section{Coefficients Metode VIF}

\begin{tabular}{|l|c|c|c|}
\hline \multicolumn{4}{|c|}{ Coefficients $^{\mathbf{2}}$} \\
\hline \multicolumn{3}{|c|}{ Model } & \multicolumn{2}{|c|}{ Collinearity Statistics } \\
\cline { 3 - 4 } \multicolumn{1}{|c|}{1} & Tolerance & VIF \\
\hline \multirow{4}{*}{\multicolumn{2}{|c|}{ (Constant) }} & & \\
\cline { 2 - 4 } & VAR.KP & .654 & 1.529 \\
\cline { 2 - 4 } & VAR.H & .607 & 1.649 \\
\cline { 2 - 4 } & VAR.KL & .754 & 1.326 \\
\hline \multicolumn{2}{|l|}{ Vumber: Data olah menggunakan SPSS 21 } \\
\end{tabular}

"Hasil perhitungan nilai Tolerance menunjukan tidak ada variabel independen yang memiliki nilai Tolerance kurang dari 0,10 yang berarti tidak ada korelasi atau hubungan antara variabel independen yang nilainya lebih dari 95\%". "Hasil perhitungan nilai variance inflation factor (VIF) juga menunjukan hal yang sama tidak ada satu variabel independen memiliki nilai VIF lebih dari 10, jadi dapat disimpulkan bahwa tidak terjadi multikolonieritas antara 
variabel independen dalam model regresi. Interprestasi" (Ghozali, 2012:108).

\section{c. Hasil Ujji Heteroskdastisitas}

"Cara atau langkah untuk mendeteksi ada atau tidaknya heteroskedastisitas dengan melihat nilai grafik plot antara nilai prediksi variabel terikat (dependen) yaitu ZPRED dengan residual SRESID".

"Deteksi ada tidaknya heteroskedastisitas dapat dilakukan dengan melihat ada tidaknya pola tertentu pada grafik scatterplot antara SRESID dan ZPRED dimana sumbu Y adalah Y yang telah diprediksi, dan sumbu $X$ adalah residual ( $\mathrm{Y}$ prediksi-Y sesungguhnya) yang telah di studentized".

\section{Gambar 7}

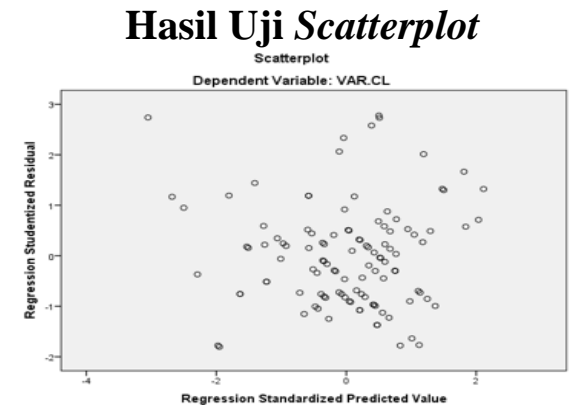

"Dasar analisis adalah Jika tidak ada pola jelas serta titik-titik menyebar diatas dan dibawah angka 0 pada sumbu Y, maka tidak terjadi heteroskedastisitas".

\section{Haasil Uji Hipotesis Penelitian}
a. Hassil Ujji Signnifikansi Simuultan (Ujii Sttatistik F)
"Pengujian hipotesis secara simultan bertujuan mengukur ada atau tidaknya pengaruh variabel bebas secara bersama-sama terhadap

$$
\begin{array}{ll}
\text { variabel terikatnya. } & \text { Hasil } \\
\text { hipotesis } & \text { yang } \\
\text { pengujian ini adalah": } &
\end{array}
$$

Tabel 6

\section{Hasil Uji F}

\begin{tabular}{|l|l|r|r|c|c|c|}
\hline \multicolumn{7}{|c|}{ ANOVA $^{\mathbf{a}}$} \\
\hline \multicolumn{2}{|c|}{ Model } & $\begin{array}{c}\text { Sum of } \\
\text { Squares }\end{array}$ & df & $\begin{array}{c}\text { Mean } \\
\text { Square }\end{array}$ & F & Sig. \\
\hline \multirow{2}{*}{1} & Regression & 1156.174 & 3 & 385.391 & 45.377 & $.000^{\mathrm{b}}$ \\
\cline { 2 - 7 } & Residual & 917.254 & 108 & 8.493 & & \\
\cline { 2 - 7 } & Total & 2073.429 & 111 & & & \\
\hline \multicolumn{7}{|c|}{ "6erdasarkan output data } \\
\hline
\end{tabular}

"Berdasarkan output data tabel diatas dapat diperoleh hasil sebagai berikut":

1) Angka F Hitung > F Tabel, sebesar 45,377>2,69 dengan signifikansi 0,000 $<0,05$.

2) Dari hasil uji Simultan (F) diatas maka menjawab $\mathrm{H}_{0}$ ditolak dan $\mathrm{H}_{3}$ diterima.

3) Hal ini menunjukkan bahwa variabel kuaalitas prodduk, haarga dan kuualitas pelayyanan secara bersama - sama berpengaruh posititf dan signifikan teerhadap kepuasan pelanggan.

\section{b. Hassil Ujji Signiifikan} Parameeter Inndividual (Ujji Sttatistik t)

Pengujian hipotesis secara parsial dimaksudkan untuk mengetahui ada atau tidaknya pengaruh variabel bebas secara parsial terhadap variabel terikat. Hasil hipotesis dalam pengujian ini adalah:

\section{Tabel 7}

\section{Hasil Uji t}

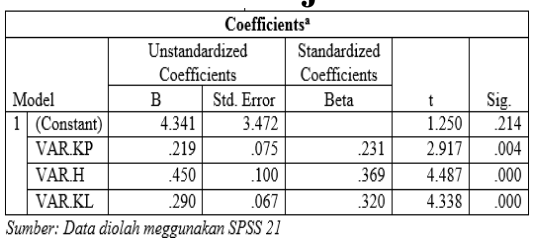


"Adapun ketentuan $t_{\text {tabel }}$ diperoleh dengan cara jumlah responden $112-4=108$, dilihat dari distribusi nilai $t_{\text {tabel }}$ maka nilai $t_{\text {tabel }}=1,659$, berikut adalah tabel perbandingan uji $\mathrm{t}$ setiap variabel".

Tabel 8

Perbaandingan Ujji t Tiaap Variabel

\begin{tabular}{|l|r|l|l|l|}
\hline Variabel & t hitung & t tabel & Sig. & Keputusan \\
\hline Kualitas Produk & 2.917 & 1,659 & 0.004 & $\mathrm{H}_{0}$ ditolak \\
\hline Harga & 4.487 & 1,659 & 0.000 & $\mathrm{H}_{0}$ ditolak \\
\hline Kualitas Layanan & 4.338 & 1,659 & 0.000 & $\mathrm{H}_{0}$ ditolak \\
\hline
\end{tabular}

Dari hasil penelitian ini variabel Kualitas produk $\left(\mathrm{X}_{1}\right)$ berpengaruh positif terhadap kepuasan pelanggan (Y), berdasarkan uji $\mathrm{t}$ pada tabel diatas $t_{\text {hitung }}(2,917)>t_{\text {tabel }}$ $(1,659)$, sehingga hasil analisis data mengindikasikan terdapat pengaruh signifikan antara variabel kualitas produk $\left(\mathrm{X}_{1}\right)$ terhadap Kepuasan pelanggan (Y), hal ini berarti bahwa semakin meningkat kualitas produk, meningkat pula kepuasan pelanggan.

Variabel kedua yakni Harga $\left(\mathrm{X}_{2}\right)$ berpengaruh positif terhadap kepuasan pelanggan (Y), berdasarkan uji t pada tabel diatas $t_{\text {hitung }}(4.487)>t_{\text {tabel }}$ $(1,659)$, sehingga hasil analisis data mengindikasikan terdapat pengaruh signifikan antara variabel Harga $\left(\mathrm{X}_{2}\right)$ terhadap Kepuasan pelanggan (Y), hal ini berarti bahwa semakin meningkat Harga, meningkat pula kepuasan pelanggan.

Variabel ketiga yakni Kualitas Layanan $\left(\mathrm{X}_{3}\right)$ berpengaruh positif terhadap kepuasan pelanggan (Y), berdasarkan uji $\mathrm{t}$ pada tabel diatas $t_{\text {hitung }}(4.338)>t_{\text {tabel }}$ $(1,659)$, sehingga hasil analisis data mengindikasikan terdapat pengaruh signifikan antara variabel kualitas layanan $\left(\mathrm{X}_{2}\right)$ terhadap Kepuasan pelanggan (Y), hal ini berarti bahwa semakin meningkat Kualitas Layanan, meningkat pula kepuasan pelanggan.

\section{Hassil Uji Anaalisis Regressi Linier Berrganda}

a. Haasil Ujji Koeefisien Deteerminasi (Adjusted $\mathbf{R}^{2}$ )

"Koefisien determinasi digunakan untuk mengetahui seberapa besar kontribusi pengaruh antara variable bebas (kualiass produk, hargaa, kualitas layanan) terhadap variable terikat (kepuasan pelanggan), maka hasil koefsien determinasi adalah sebagai berikut":

\section{Taabel 9}

Hasil Koeefisien

Deeterminasi

\begin{tabular}{|l|c|r|r|c|}
\hline \multicolumn{5}{|c|}{ Model Summary } \\
\hline Model & R & R Square & Adjusted R Square & $\begin{array}{l}\text { Std. Error of } \\
\text { the Estimate }\end{array}$ \\
\hline 1 & $.747^{\mathrm{a}}$ & .558 & .545 & 2.914 \\
\hline $\begin{array}{l}\text { a. Predictors: (Constant), } \\
\text { VAR.KL, VAR.KP, VAR.H }\end{array}$ \\
"Berdasarkan \\
"Berdasarkat
\end{tabular} data tabel di atas dapat diperoleh hasil sebagai berikut":

1) Angka Koefisien $R$ sebesar 0,747. Artinya korelasi Kualitas Produk, Harga dan Kualitas Layanan terhadap Kepuasan pelanggan sebesar 0,747. Hal ini dapat dikatakan bahwa adanya hubungan positif sebesar 0,747 antara variabel Kualitas Produk, Harga dan Kualitas Layanan terhadap Kepuasan pelanggan. 
2) Berdasarkan nilai dari koefisien uji determinasi Adjusted $R$ Square sebesar 0,545. Data tersebut mengindikasikan bahwa Kualitas Produk, Harga dan Kualitas Pelayanan terhadap variabel kepuasan pelanggan memberikan kontribusi sebesar $54,5 \%$. Sisanya sebesar $45,5 \%$ dijelaskan oleh vaiabel lain diluar penelitian ini.

\section{b. Hasil Koefisien Persamaan Regresi Linier Berganda}

"Hasil regresi linier berganda mempengaruhi kualiti produk, harga dan kualiti perkhidmatan terhadap kepuasan pelanggan seperti berikut":

\section{Tabel 10}

\section{Hasil Koefisien Persamaan}

\section{Regresi Linier Berganda}

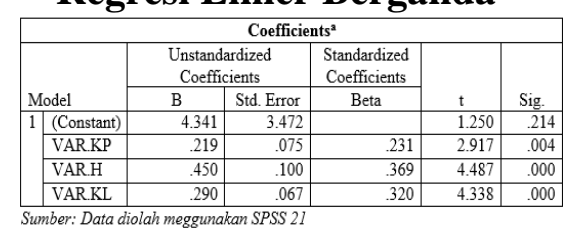

" Pada output ini, nilai pekali persamaan regresi dinyatakan. Dalam kes ini, persamaan regresi berganda yang digunakan ialah":

$$
Y=a+b_{1} x_{1}+b_{2} x_{2}+b_{3} x_{3}+\varepsilon i
$$

\section{Dimana:}

Y : Kepuasan Pelanggan

a : konsstanta

$\mathrm{b}_{1}-\mathrm{b}_{3} \quad$ : Koeffisien Regreesi

$\mathrm{X}_{1} \quad$ : Kualitas Produk

$\mathrm{X}_{2} \quad$ : Hargga

$\mathrm{X}_{2} \quad$ : Kualittas Layanan

ei : Standard Error

Dari output didapatkan model persamaan regresi:
$Y=4.341+0.219 \times 1+0.450 \times 2+0.290 \times 3+\varepsilon i$

"Persamaan di atas adalah hasil perhitungan SPSS. 20 yang dilihat dari nilai beta unstandardized coefficient, berikut ini adalah pembahasan yang mengenai hasil uji reggresi linierr berganda yang menjelaskan bagaimana tingkat pengaruh atau besarnya pengaruh antar varuiabel bebas terhadap variable terikat":

1) "angka tetap (constant) sebesar 4,341 membuktikan bahwa jika kuualitas prooduk, haarga dan kuaalitas laynan dianggap konstant, maka loyyalitas planggan (Y) akan meningkat sebesar 4,341".

2) "Variable Kualtas Prooduk (X1) berpengaruh secara positif terhadap Kepuasan pelanggan (Y) dengan nilai koefisien sebesar 0.219 yang artinya jika variabel Kualitas Produk $\left(\mathrm{X}_{1}\right)$ meningkat satu satuan dengan asumsi Harga $\left(\mathrm{X}_{2}\right)$ dan Kualitas Layanan $\left(\mathrm{X}_{3}\right)$ tetap, maka kepuasan pelanggan (Y) akan naik sebesar 21,9\%".

3) "Variabel Harga $\left(X_{2}\right)$ berpengaruh secara positif terhadap Kepuasan pelanggan (Y) dengan nilai koefisien sebesar 0.450 yang artinya jika variabel Harga $\left(\mathrm{X}_{2}\right)$ meningkat satu satuan dengan asumsi kualitas produk $\left(\mathrm{X}_{1}\right)$ dan kualitas layanan $\left(\mathrm{X}_{3}\right)$ tetap, maka kepuasan pelanggan (Y) akan naik sebesar $45 \% "$ ". 
4) "Variabel Kualitas Layanan $\left(\mathrm{X}_{3}\right)$ berpengaruh secara positif terhadap Kepuasan pelanggan (Y) dengan nilai koefisien sebesar 0.290 yang artinya jika variabel kualitas layanan $\left(\mathrm{X}_{3}\right)$ meningkat satu satuan dengan asumsi kualitas produk $\left(\mathrm{X}_{1}\right)$ dan harga $\left(\mathrm{X}_{2}\right)$ tetap, maka kepuasan pelanggan (Y) akan naik sebesar 29\%".

berdasarkan pada nilai koefissien reggresi bahwa variable bebas (independen) yang paling berpengaruh terhadap kepuasan pelanggan adalah variabel harga, hal tersebut dilihat berdasarkan nilai standardizd coefficient beta terbesar yaitu sebesar 0,369 .

\section{KESIMPULAN DAAN SARAN}

\section{A. Kesimpulaan}

Hassil penlitian menyatakan bahwa seluruh variable yang terdiri dari kualitas prodduk, kwalitas layanan terhadap kepuasan pelanggan, berikut adalah hasil kesimulan dari hasil penelitian:

1. "Hasil menyatakan bahwa variable yang berpengarh secara simultan yaitu kualitaas produuk dan kualitas pelayanan dengan signifikan berpengaruh terhadap variabel loyalitas pelanggan, hasil terlihat berdasarkan nlai signifikan di bawah 0,05 ".

2. "Hasil uji t (parsial) menemukan bahwa seluruh variabel independen (ekuitas merek dan kualitas pelayanan) berpengaruh secara signifikan loyalitas pelanggan".
3. "Variabel yang paling memiliki pengaruh terhadap loyalitas pelanggan adalah kualitas pelayanan terlihat berdasarkan nilai beta terbesar, yaitu sebesar $0,670 "$ ".

\section{B. Saran}

Setelah dilakukan analisis dan membuat suatu kesimpulan yang didasarkan ppada teori dan hasil dilapangan maka terdapat saran diungkapkan, yaitu:

1. Bagi perusahaan

a. Harus mlakukan penigkatan suatu layanan terhadap pelanggan dengan memberikan pelatihan dan pendidikan kepada karyawan.

b. Dalam meningkatkan suatu pelayanan dan keinginan pelanggan diharapkan bagi perusahaan melakukan riset terhadap pelanggan.

2. Bagi akademisi

a. Untuk penelitian selanjutnya melakukan penambahan variable, karena berdasarkan analisa masih terdapat $26,4 \%$ yang mampu mempengaruhi variael kepuasan pelanggan di luar penelitian ini.

b. Diharapkan menambah sampel agar meningkatkan kualitas penelitian.

\section{DAFTAR PUSTAKA}

Algifari, 2010. Analisis Regresi. Yogyakarta

Agustina Vina,Yoestini.2012. Analisis Pengaruh Kualitas

Pelayanan, Kepuasan Pelanggan ,dan Nilai Pelanggan dalam 


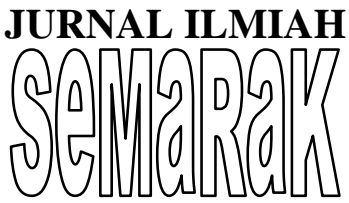

meningkatkan Loyalitas Pelanggan Joglo Semar Bus. Journal Of Management. Volume 1 No 1. Hal 1-11: Fakultas Universitas Diponogoro.

Arikunto, Suharsimi. 2010. Prosedur Penelitian Suatu Pendekatan Praktek. PT. Rineka Cipta. Jakarta.

Ariawan, Iwan, 1998. Besar dan Metode Sampel Pada Penelitian Kesehatan. Jurusan Biosatistik dan Kependudukan Fakultas Kesehatan Masyarakat Universitas Indonesia.

Assauri, Sofian.2012. Manajemen Produksi dan Operasi. LPFE Universitas Indonesia. Jakarta.

Azhari, 2001. Hubungan Antara Faktor Internal dan Faktor Eksternal Dengan Prestasi Belajar Siswa Di SPK Depkes Lubuk Linggau Tahun 2001. Tesis Program Pasca Sarjana Ilmu Kesehatan Masyarakat

Chandra, Gregorius. 2011. Strategi dan Program Pemasaran. Andi Offset, Yogyakarta

Fandy Tjiptono, 2008. Strategi Pemasaran.

Yogyakarta.:Andi.

Ghozali, Imam. 2005, Aplikasi Analisis Multivariate dengan Program SPSS, Semarang: BP Undip Semarang.
G.R Terry \& Rue, Leslie W. Rue.2010

Dasar-Dasar Manajemen.

Bumi Aksara. Jakarta

Gulla, Rendy dan Oroh, Sem George.2015. Analisis Harga,Promosi dan Kualitas Pelayanan Terhadap Kepuasan Konsumen Pada Hotel Manado Grace Inn. Jurnal EMBA Vol.3 No.1 Maret 2015, Hal.1313-1322.

Kottler, Philip dan Gary Amstrong. 2001. Manajemen Pemasaran. Gramedia, Jakarta

Kottler, Philip dan Gary Amstrong. 2001. Principle of Marketing (edisi 14). Prentice Hall.

Kottler, Philip. 2002. Manajemen Pemasaran. Prenhallindo, Jakarta.

Kottler, Philip dan Keller, Kevin Lane. 2008. Manajemen Pemasaran (edisi 12) PT.Indeka, Jakarta.

Kottler, Philip. 1997. Manajemen Pemasaran, Analisis Perencanaan, Implementasi, dan Kontrol. Prenhallindo, Jakarta.

Kottler, Philip, et.al. 2003. Rethinking Marketing, Sustainable Market-ing Enterprise di Asia. Prenhallindo, Jakarta.

Kottler Philip, 2012. Manajemen Pemasaran, Edisi Ketiga Belas, Jilid I Penerbit PT. Macanan Jaya Cemerlang, Jakarta.

Lovelock and Wright. 2011. Principle of Service Marketing and Management.Prentice Hall 


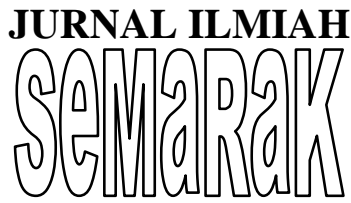

Inc, Upper Saddle River, New Jersey. USA.

Lupiyoadi, Rambat. 2001. Manajemen Pemasaran Jasa. Salemba Empat, Jakarta.

Lupiyoadi, Rambat dan Hamdani. A. 2006. Manajemen Pemasaran Jasa Edisi 2. Salemba Empat, Jakarta.

Nitisemito, A.S. 2000. Marketing. Cet.Keenam, Ghalia Indonesia, Jakarta.

Parasuraman, Valarie A. Zheitaml and Leonard L. Berry 1998. Reassesment of expectation as a comparison standard in measuring service quality: Implication for further research. Journal of Marketing. Chicago. Vol.58, No. 1;

Radiosunu, 2001. Manajemen Pemasaran suatu Pendekatan Analisis, Edisi Kedua. Cetakan Kelima. Penerbit. BPFE. Yogyakarta.

Rangkuti, Freddy. 2003. Measuring Customer Satisfaction : Tehnik Mengukur dan Strategi Meningkatkan Kepuasan Pelanggan. PT. Gramedia Pustaka Utama, Jakarta.

Rangkuti, Freddy. 2016. Riset Pemasaran. PT. Gramedia Pustaka Utama, Jakarta.

Riduwan. 2008, Metode dan Teknik Penyusunan Tesis, Penerbit ALFABETHA, Bandung.
Richard, Darmawan Andriyanto. 2010. Analisis pengaruh internet marketing terhadap pembentukan word of mouth dan brand awareness untuk memunculkan intention to buy. Salatiga, Jateng: Universitas krosten Satya Wacana.

Rostya, Rerry Albertus, Yoestini. 2012. Analisis Pengaruh Harga, Kualitas Produk, Dan Kualitas Pelayanan Terhadap Kepuasan Pelanggan.Diponogoro Bussines Review. Volume 1, No. 1, Hal 1-9. Universitas Diponogoro. Semarang

Sekaran, Uma. 2000. Research methods. John Wiley \& Sons. Inc.

Simamora, Bilson. 2002. Panduan Riset Perilaku Konsumen. PT. Gramedia Pustaka Utama, Jakarta.

Simamora, Bilson. 2003. Membongkar Kotak Hitam Konsumen, PT. Gramedia Pustaka Utama, Jakarta.

Stanton, William J. 2000. Prinsip Pemasaran, Edisi Keempat Belas jilid 1, Terjemahan oleh Y. Lamarto. Erlangga, Jakarta.

Sugiono.2012. "Metode Penelitian Kuantitatif Kualitatif dan R\&D”. Penerbit CV. Alfabeta.Bandung.

Sunarto, 2003. Manajemen Pemasaran. Edisi Pertama. Cetakan 
JURNAL ILMIAH

(2) 0 , G0,

(5) ${ }^{\prime}\left(\begin{array}{l}0 \\ 1\end{array}\right)$
P-ISSN 2615-6849, E-ISSN 2622-3686

Jurnal Semarak,Vol. 2,No.1, Februari 2019, Hal (1- 20)

@Prodi Manajemen Fakultas Ekonomi Universitas Pamulang

Pertama. Penerbit BPFEUST, Yogyakarta.

Swastha, Basu dam T. Hani Handoko, 2000.

Manajemen

Pemasaran Modern, Edisi Kedua. Penerbit Liberty, Yogyakarta.

Tjiptono, Fandy. 2000. Perspeltif Pemasaran dan Pemasaran Kontemporer. Andi Offset. Yogyakarta.

Tjiptono, Fandy. 2002. Manajemen jasa, Edisi II, Cetakan ketiga. Andi Offset. Yogyakarta.

Tjiptono, Fandy dan Gregorious Candra. 2005. Service, Quality, and Satisfaction. Andi Offset. Yogyakarta.

Vanessa,Gaffar. 2013. Customer Relationship Management and Marketing Public Relation. Alfabeta. Bandung

Jakarta. 